日本建築学会技術報告集 第23号, 530，2006年 6 月 AlJ J. Technol. Des. No. 23, 530, Jun., 2006

石田建一 [積水ハウス (株) 温暖化防止研究所 所長・工博] 壁面緑化は，パネル化により比較的簡単に実施可能になりつつあ るが, ヒートアイランドの防止や冷房負荷削減の定量的な効果は明 らかになっていない。本論文は，壁媔緑化を1ヶ月間にわたり計測 し, 蒸発特性や熱収支の定量的な評価を行ったものである。植物の 熱収支の計測は難しいが，ここでは蒸発に対しては重量を直接計測 し比較的精度良く求めており，放射・対流の分離には植物を模した SAT 計ユニットを用いたことがユニークである。解析結果として， 壁面緑化における植物の蒸発散による温度上昇を抑える効果を確認 しているが, 今後の効果的な壁面緑化の奏施のためには，より一層 の計測データの蓄積が望まれる。
萩島 理 [九州大学総合理工学研究院エネルギー環境共生工学部門 助教授・ 工博]

本報告で提示されたデ一夕は，現行の都市気候モデルに応用可能 なパラメータ「蒸発効率」が提示されているという点で, 極めて有 用性の高いものと言えよう。植物を模擬したSAT 計により伝達率 を推定するという手法は既往研究と同一のものではあるが, 表面温 度測定など手法の細部にきめ細かな工夫が見られ，より高精度な データが得られていると思われる。計測機器や緑化システムの構造, 寸法，植物種類などが既往研究と異なっているにも関わらず，蒸発 効率が $0.1 \sim 0.2$ という類似の値が得られている点は非常に興味深 W。

重量法による蒸散量に比へSAT 計法による蒸散量が 4 割ほど過 小評価となったのは，小試験体を用いた重量法の測定值がオアシス 効果の影響を受けていたためと推察されるが，残念ながら本稿では 詳しい記述はなされていない。壁面緑化の推定手法確立のためには， この点について更に詳しい解析が行われる事を期待したい。

\title{
自治体版 CASBEEの概要＼cjkstart建築物総合環境性能評価システムの開発（その3）
}

遠藤純子, 村上周三, 伊香賀俊治, 吉澤伸記, 佐藤正章 237

木俣信行 [鳥取環境大学環境情報学部環境デザイン学科 教授・工修 $]$ このところわが国の市民が建築物を見る目は，構造強度偽装事件 によって増幅され，厳しいものがある。しかしこの事件の発生を待 つまでも無く，わが国のストックとしての建築物の質的水準は，持 続可能な社会を支えるものとしては世界に誇れる水準とは言い難 い。本報告は，わが国主導で開発された建築物の質を環境の観点か ら測る評価システムとしての CASBEEによって，地域の建築物の 総合的な環境性能の向上に資する自治体の対応の可能性を紹介して おり，その意味で今日のわが国の建築界が抱之ている課題に応える 報告と言える。

報告によるとCASBEE は，建築主にインセンティブを与えるた めに，各自治体による評価基準や重み係数などの操作が可能とされ ているが，その運用にあっては公平性，公正性そして合目的性が問 われるものと考えられる。ここではそうした自治体の対応上の課題 や方向については示されていないので，目指された成果が如何に得 られるかは別の報告に期待した。
奥宮正哉 [名古屋大学大学院環境学研究科 教授・工博] 政令指定都市における「建築物環境配慮制度」への，環境効率を 建築物の環境性能評価に展開した CESBEEの導入状況に関する報 告である。特にCASBEE を用いた性能評価が簡略かつ正確に行な われるよう, また各自治体の特性（地域特性）が項目の追加, 項目 毎の重みの変更などによって評価に反映されるよう，どのような努 力が払われてきたかがよくわかる。しかしながら最初に導入された 名古屋市においてもまだ導入後 2 年しか経過しておらず，建築主に 本手法を取り入れることの意義やメリット（容䅡率の優遇などのイ ンセンティブ以外の）が十分に理解されているか，またそれによっ て建築物の環境性能がどのように向上してきているかは今後の検討 が必要である。さらに自治体，建築主，設計者そして住民の連携に より本手法が各地域の環境ビジネスまでもを創成するものとなって いくためには何をなさなければならないかなどの今後の提案が期待 される。

ヒートアイランド現象緩和に関する評価システム構築のための CFDによる感度解析

村上周三, 大岡龍三, 足永靖信, 大黒雅之, 谷本 潤, 持田 灯, 松縄 堅, 河野孝昭 241

森山正和 [神戸大学工学部建設学科 教授・工博]

評価項目の重み付けを求めるために感度解析を行った報告であ り，対策効果の相対的な関係を議諭するのに大変興味深い。いわば 対策効果の一般解を提示しようとするものである。CFDや 1 次元モ デルを用いて求めた一般解には必然的にモデルの仮定やそれによる 適用限界が存在する。現実には，周囲の様々な条件を考虑せずして 敷地内要因のみで評価することはないであろう。もう一つの危惧は 本質的なメカニズムが理解されず機械的に適用される場合である。 マニュアルで機械的に判断する手順を強調しすぎると複雑な現象で は矛盾を起こす可能性もある。結局，多くの事例で試されて，常識 的にも問題がないかを確認しながら相対的な評価点を再チェックし てゆくことが重要であろう。著者らの姿勢からも伺えるが，たとえ 説明しにくい結果が出たとしてもオープンに議論を重ね，より良い ものに発展させる継続的な努力が必要とされよう。
加藤信介 [東京大学生産技術研究所 5 部 教授・工博] 時期に適った報告である。昨今，夏季の暑熱問題がマスコミに取 り上げられ，都市の暑熱問題の一因としてヒートアイランド現象が 取り上げられ，国民的関心を呼んでいる。ヒートアイランド現象が 都市の暑熱問題の一因であるならば，そのヒートアイランド現象自 身に对して，どのようなパラメータがどの程度の感度を持っている か，そのパラメー夕を変化させた場合，ぞの程度の影響が生じるか という検討は，極めて本質的な検討である。検討は，ヒートアイラ ンド現象を説明する物理モデルを作成し，この物理モデルを用いて, その影響の感度解析を行うことで進められる。この報告は物理モデ ルに対しては学術的検討が既になされ，ある程度の信頼性が確保さ れたモデルを用いてスタディを行ったものなので，原著論文ではな く技術報告として報告されたのであろう。

評者としては，技術報告と論文との境を改めて問う報告と思われ る。 